\title{
Dynamic Role and Importance of Multi-Kingdom Communities in Mediterranean Wood-Pastures
}

\author{
Eleni Topalidou $^{1, *}$, Alexandra D. Solomou ${ }^{2} \mathbb{D}$, Susana S. Santos ${ }^{3}$, Evdokia Krystallidou ${ }^{4}$, Styliani Kakara ${ }^{2}$ \\ and Konstantinos Mantzanas 5 (D)
}

1 Hellenic Agricultural Organization “DEMETER", Forest Research Institute, Vasilika, 57006 Thessaloniki, Greece

2 Hellenic Agricultural Organization "DEMETER", Institute of Mediterranean \& Forest Ecosystems, Terma Alkmanos, Ilisia, 11528 Athens, Greece; solomou@fria.gr or alexansolomou@gmail.com (A.D.S.); estel.kakara@gmail.com (S.K.)

3 Department of Agroecology, Aarhus University, 4000 Slagelse, Denmark; suss@agro.au.dk

4 American Farm School, Marinou Antipa 54, P.O. Box 23, 55102 Thessaloniki, Greece; vickykrystallidou@yahoo.co.uk or ekryst@afs.edu.gr

5 Laboratory of Rangeland Ecology, Aristotle University Thessaloniki, 54124 Thessaloniki, Greece; konman@for.auth.gr

* Correspondence: etopal@fri.gr; Tel.: +30-2310-461-172

Citation: Topalidou, E.; Solomou, A.D.; Santos, S.S.; Krystallidou, E.; Kakara, S.; Mantzanas, K. Dynamic Role and Importance of Multi-Kingdom Communities in Mediterranean Wood-Pastures. Sustainability 2021, 13, 10179. https:/ / doi.org/10.3390/su131810179

Academic Editor: Daniela Smiraglia

Received: 8 August 2021

Accepted: 6 September 2021

Published: 11 September 2021

Publisher's Note: MDPI stays neutral with regard to jurisdictional claims in published maps and institutional affiliations.

Copyright: (c) 2021 by the authors. Licensee MDPI, Basel, Switzerland. This article is an open access article distributed under the terms and conditions of the Creative Commons Attribution (CC BY) license (https:/ / creativecommons.org/licenses/by/ $4.0 /)$.

\begin{abstract}
Wood-pastures are among the most valuable types of farmland for ecosystem services, including biodiversity, landscape, soil protection, water management and cultural values. This paper reviews the scientific literature regarding the dynamic role and importance of plant, fungal and ruminant communities in Mediterranean wood-pastures and assesses the favorable and unfavorable aspects of their occurrence through grazing management. The grasslands of the Mediterranean region play an important role both in forage material production and the conservation of biodiversity in plant communities and at the landscape level. These two management purposes are not conflicting but complementary when the management is based upon the knowledge of the effect of grazing on the ecology of these ecosystems. Conclusively, vascular plant, fungal and ruminant communities have a strong influence on ecosystem structure and functioning and they play a key role in many ecological services. Hence, integrated studies which combine multi-level ecological research are essential in order to identify regional and/or national needs in terms of biodiversity, genetic resources, sustainable rural development and conservation policies.
\end{abstract}

Keywords: flora; fungi; ruminants; grazing; pastures; ecosystem services; ecology; utilization; Mediterranean

\section{Introduction}

Wood-pastures are essential elements of landscapes and are recognized for their significant ecological value worldwide. Wood-pastures occupy around 20.3 million ha in the 27 EU member states, which represents around $4.7 \%$ of European land, with the area of grazed wood-pasture estimated to be 15.1 million ha [1]. In wood-pastures, livestock grazing co-occurs, with scattered trees and shrubs constituting the most valuable types of farmland for biodiversity [2]. It is widely accepted that there are many ecological and economic interactions among flora and fauna (e.g., fungal, nematode and ruminant communities, etc.) in these landscapes. The interactions among species are often complex and they may exhibit numerous positive or negative effects which are not easily noticed, observed or measured. Human activity is linked with the delivery of goods by the ecosystems; often, the survival and well-being of rural people is based on the production of the "ecosystem goods" $[3,4]$.

Either due to the increased farming intensity or land abandonment during the last few decades, some major threats for the biological activity of several ecosystems have 
emerged $[5,6]$. Therefore, recently developed conservation management strategies emphasize biodiversity conservation and ecosystem multifunctionality. The concept of agroforestry has evolved during the last few years, and under this concept, many different approaches are integrated into management practices in order to enhance the sustainable production of ecosystem goods (timber, food, medicinal plants, animal production, etc.) and balance productivity with environmental protection (enhancement of biodiversity, reduction in nutrient losses, pest and disease control, etc.). In many regions, such agroforestry systems were traditionally used for decades and consisted of important elements of rural landscapes (forest land, coppice forests and orchards) [7].

Wood-pastures are typical examples of successful agroforestry systems (multifunctional land use). By definition, wood-pastures are landscapes which are covered by a combination of a tree and a pasture cover and are regularly grazed by natural large grazers or by domestic livestock or both $[2,8]$. The structural diversity of wood-pastures varies considerably across Europe [8]. This variation is mainly attributed to the grazing intensity and tree thinning (selective logging), two practices which substantially determine the vegetation structure and dynamics in those ecosystems $[2,8,9]$. Wood-pastures are valuable elements of socially, ecologically and economically important landscapes in Europe, and their traditional management has been practiced for centuries [10] often, wood-pastures are regarded as forms of cultural heritage in Europe [10]. Mediterranean oak woodlands, Montados in Portugal and Dehesas in Spain have long been acknowledged as potential land-use systems of high nature and social value providing relevant ecosystem services and biodiversity conservation [11]. Cultural services (particularly the aesthetic and recreational values of the landscape), supporting services (biodiversity maintenance) and some regulating services (particularly fire risk prevention) were clearly recognized by both farmers and citizens, with different degrees of importance according to their particular interests and objectives [12]. The diversity of production is characteristic of these systems, and the long-term ecological sustainability derives from the sub-optimization of the resources for many centuries [13]. However, wood-pasture ecosystems in most European countries have been noticeably degraded during recent decades, and therefore, they are considered as threatened landscapes which need to be protected and conserved $[1,10]$.

According to Bergmeier et al. [10], there are twenty-four types of wood-pastures which are categorized based on the following geobotanical criteria: (i) region, (ii) structure, (iii) land use and (iv) species composition. Moreover, they are categorized according to the different bioclimatic zones in Europe as boreal, nemoral, meridional, hemiboreal and submeridional [9]. Because of their dynamic nature (spatial and temporal variations due to climatic events, traditional management, pests, herbivores, etc.), all of these different wood-pasture types exhibit exceptional ecological values; they provide an important habitat for a wide range of different organisms and are therefore considered important for regional biodiversity; they pose important restoration possibilities for the maintenance and conservation of genetic resources $[2,10]$.

The degradation of biodiversity observed in wood-pastures during recent decades is mostly attributed to (i) abandonment, which leads to the formation of closed-canopy forests; (ii) intensification, that leads to the development of crop monocultures; (iii) failure of woodpasture regeneration and woodland aging; (iv) management methods (overgrazing, tree thinning, etc.); (iv) pest problems (devastating insects and/or diseases) [8,13]. Woodpastures are still widely distributed in the Mediterranean and Balkans, areas where their traditional usage is still retained to some extent [8]. The conservation of wood-pastures in the Mediterranean is linked with the traditional practice and their appropriate management is very important for the maintenance of their biodiversity, ecological and economical value.

Hence, the present study aimed to investigate the dynamic role of vascular plant, fungal and ruminant communities in Mediterranean wood-pastures, as well as the favorable and unfavorable factors that influence their occurrence through grazing management. Moreover, it highlights how grazing is linked with animal welfare and can improve the quality of livestock products. This short review may be useful for future studies that seek to 
expand the information regarding the dynamic role and importance value of biodiversity in Mediterranean wood-pasture landscapes.

\section{Literature Review}

A review of the scientific literature about the dynamic role and importance of multikingdom communities in Mediterranean wood-pastures (Figure 1) was conducted. The keywords used for the Boolean search [14] included words such as "flora", "fungal", "ruminant", "grazing", "ecosystem", "ecology", "pastures", "utilization", "services", "landscape" and "Mediterranean". A total of 320 articles and abstracts were identified through the database searches. After removing 122 duplicates, 198 records were studied based on the title and abstract.

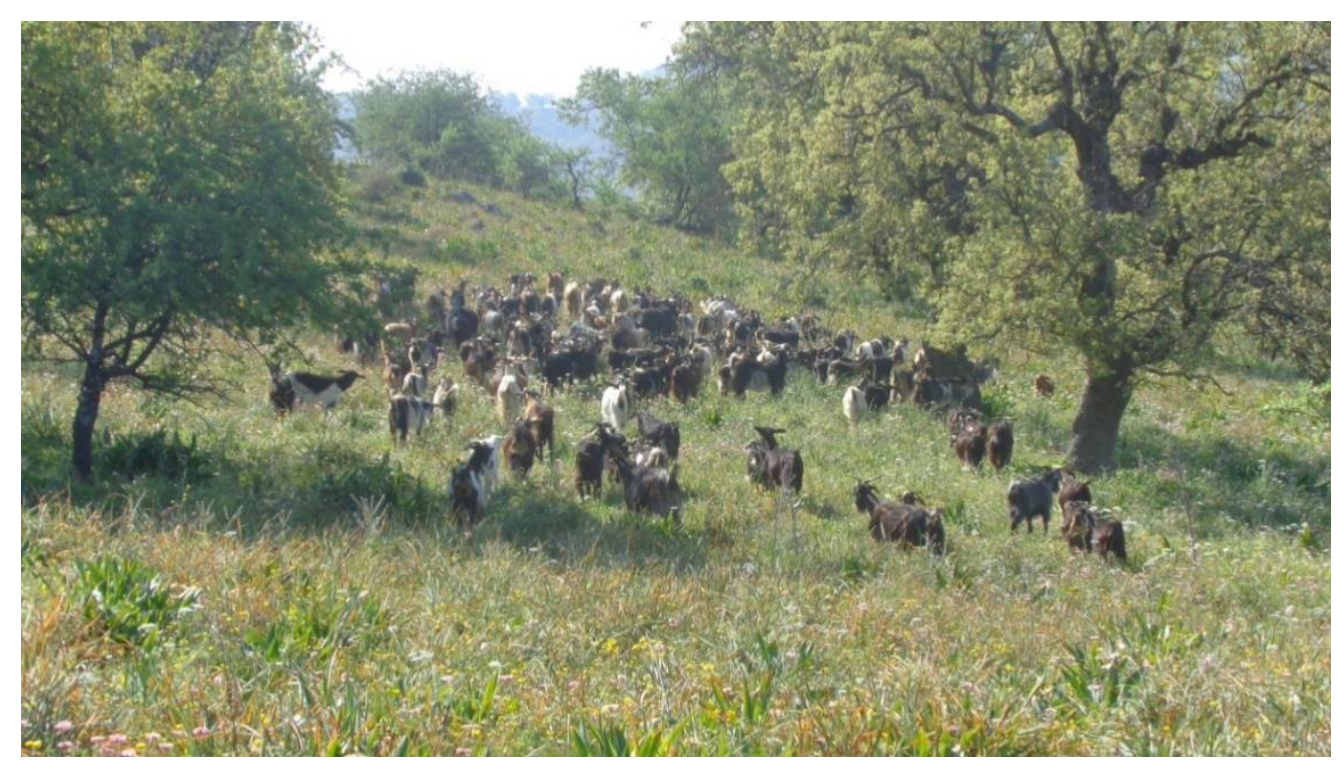

Figure 1. Example of a Mediterranean wood-pastures (the photo was taken at wood-pastures of Xiromero/Aetolia-Acarnania $\left(38^{\circ} 35^{\prime} 00.43^{\prime \prime} \mathrm{N}, 21^{\circ} 13^{\prime} 21.56^{\prime \prime}\right.$ E) in western Greece by Dr. K. Mantzanas). The vegetation of Xiromero/Aetolia-Acarnania mainly includes valonia oak (Quercus ithaburensis subsp. macrolepis), in combination with phrygana and herbaceous plants.

The research studies were reviewed from 10 perspectives. These were: (i) general characteristics, (ii) Mediterranean basin, Mediterranean climate, (iii) dynamics of the communities in the wood-pastures of Mediterranean landscapes, (iv) important meadow plant families, (v) role of grazing in plant diversity of Mediterranean landscapes, (vi) the importance of fungi in ecosystem processes, (vii) the dynamics of fungal communities in Mediterranean wood-pasture landscapes, (viii) the effect of grazing on fungal biodiversity in Mediterranean wood-pastures, (ix) the effect of woodland grazing on ruminants and $(x)$ products and PDO.

\section{Mediterranean Ecosystems}

\subsection{General Characteristics}

In five regions of the world and particularly in the Mediterranean basin, California, Chile, South Africa and southwestern and southern Australia, there are areas with a Mediterranean climate, i.e., a climate characterized by dry summers and wet, mild winters [15]. These areas are all grouped between 300 and 400 south or north of the equator [16]. The Mediterranean climate can be defined as a transition system between a temperate and dry tropical climate [15]. The main feature that distinguishes it from other types of climates is the alternation of mild, wet winters with hot, dry summers [17]. Rainfall is the most important qualification in Mediterranean regions, but its quantity and distribution creates very different conditions, particularly in terms of the extent of summer drought [17]. 
According to Aschmann [18], the Mediterranean climate has rainfall ranging between $275 \mathrm{~mm}$ and $900 \mathrm{~mm}$, with at least $65 \%$ falling in winter. For most Mediterranean climate regions around the globe, the models consistently project drier futures [19]. According to Vamvaka [20], regardless of the total amount of rainfall, seasonality is the most important parameter for the climate of the Mediterranean basin. Generally, in these areas there are strong seasonal fluctuations in many natural resources, with moisture being the most important of these. Water is abundant during the winter, but during summer is a limiting factor for most organisms. The nutrients are at low levels and their availability varies seasonally [21]. These areas not only have the same climate, but they are also dominated by similar natural vegetation [15]. Mediterranean ecosystems are characterized by evergreen sclerophyllous shrubs or small trees, and even though these areas are geographically distant, the physiognomy of the vegetation is similar [14]. Of the five existing macro-climates in the world, the Mediterranean is the one with the greatest diversity of shrub plants, being consider one of the great biodiversity hotspots worldwide [22].

\subsection{Mediterranean Basin}

The geographical location of the Mediterranean basin between Europe, Asia and Africa (Figure 2), the complex geological history and climatic conditions created an unusual geological and topographical variety with high mountains, peninsulas and one of the largest archipelagos in the world, which contains several hundred islands and islets [23,24].

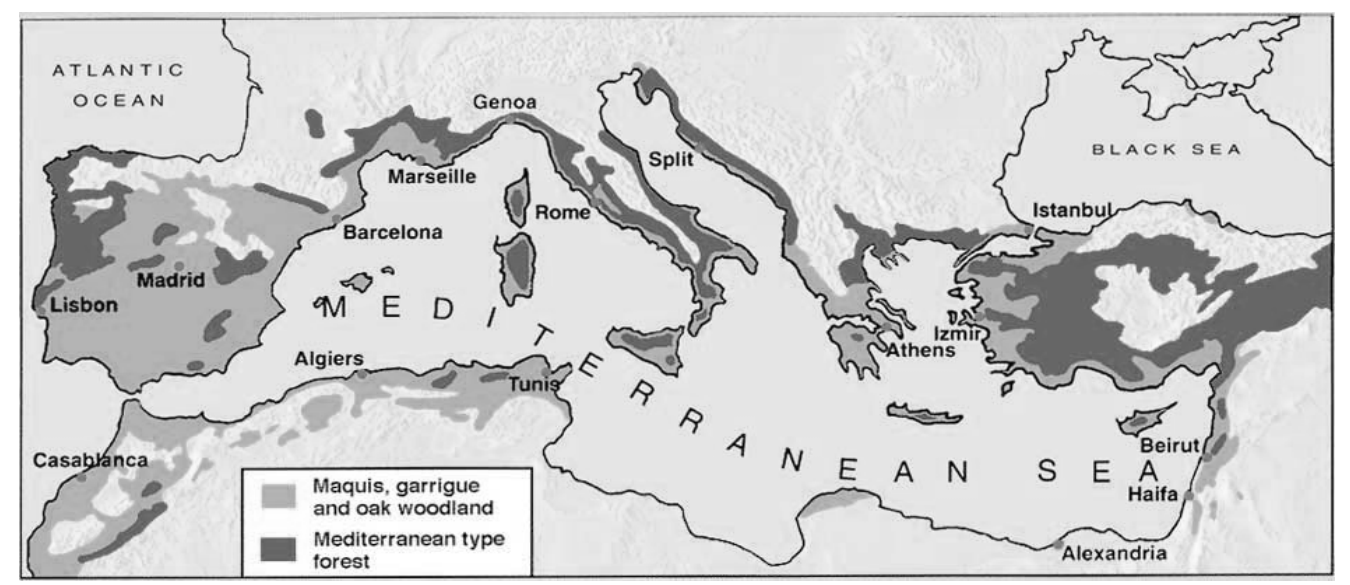

Figure 2. Map of the Mediterranean basin [17].

The geological diversity of the area, combined with the peculiarities of the climate and the special regime nutrients, are the key factors that shaped the landscape around the Mediterranean. It is known that the Mediterranean basin constitutes one of Earth's richest biodiversity hotspots [25]; however, nowadays it is threatened by several human activities [26] including grazing, clearing and fire [27].

\subsection{Dynamics of the Communities in the Wood-Pastures of Mediterranean Landscapes}

Ecological patterns and ecological functions and processes are strongly linked with each other, and there may be a two-way dynamic interaction between pattern and process $[28,29]$. Land uses in the past have resulted in a wide range of landscape patterns. The influence of these patterns on ecological processes may persist for long periods [30]. It is known that the growth, mortality and recruitment of individuals are the major factors influencing the dynamics of plant communities [31]. Additionally, different environmental factors affect the distribution and structure of plant populations [32].

The composition of the native vegetation of an area undergoes constant change from season to season, from year to year, and during long periods. By the term "composition", we mean the percentage of soil cover of the different species of native vegetation of an area. So, we can draw conclusions from the changes in the composition of native vegetation, 
which pose great importance for the factors that depend on them. Some changes in the composition of vegetation have a permanent character, while others are simply temporary. Still, other changes are entirely caused by natural causes such as variations in climatic conditions, grazing animals, fires and other disturbances [22]. It is a fact that severe landscape changes can be found in the Mediterranean basin because of its extensive land use [33]. Mediterranean landscapes are the outcome of the combined action of climate, types of substrates, topographical forms, vegetation and historical human activity going back thousands of years. In the Mediterranean basin, people of Paleolithic times used fire to hunt and gather food [34-37], and afterwards, millennia of severe pressure that provoked burning, cutting and grazing non-arable lands, clearing, terracing, and cultivating arable areas, brought about a large number of strongly human-modified landscapes [38]. As the decades pass, it is observed that in the northern rim of the Mediterranean, the combination of industrialization and abandonment of the countryside led to many abandoned fields, increasing the cover of early-succession species (many of which are very flammable) and changing the landscape pattern $[39,40]$.

A wood-pasture can consist of rich or poor flora. The plants that make up the flora of the wood-pastures are distinguished by the herbs that make up the herbaceous vegetation and by the shrubs and trees, which are the woody vegetation. The physicochemical properties of the soil, the climatic conditions of each region, the relief of the soil, the altitude and the anthropogenic effects contribute to the formation of the vegetation of a region [41,42].

Climatic conditions prevailing in Mediterranean environments, especially during the long, hot and dry summer induce specific phenological, morphological, physiological and ecological strategies in plants that live in these environments [4]. High temperatures that prevail in the summer in combination with a simultaneous lack of water drain herbaceous vegetation in the understory of clusters as well as portions of the standing woody biomass. This material and the dry herbaceous phytomass form a highly combustible litter [43]. Several Mediterranean plant species produce combustible substances, such as essential oils and resins. Together with climatic conditions, these plants can "support" the start and spread of fires. The Mediterranean ecosystems have evolved under the periodic action of fire, producing long-lasting landscape patterns [44]. Furthermore, it may sweep away [45] or contribute to the invasion [46,47] of different species and thus trigger changes in landscape and ecosystem processes. Post-fire succession in the Mediterranean plant communities is a way of autosuccession $[43,48-55]$ in which the burned community maintains the floristic identity with time, as observed previously by Hanes [56]. Different studies concluded that plants have the ability to dominate these fire-prone ecosystems by evolving numerous adaptation mechanisms, particularly concerning post-fire regeneration [33,36,57].

\subsection{Important Plant Families in Meadows}

The most abundant and economically important families are the grasses (Poaceae) and legumes (Fabaceae), as they are grown to meet basic dietary needs [41]. These plant families are highly adaptable and can withstand the adverse conditions of grazing and cutting, and are cultivated for grazing, hay, silage and for fruit harvesting. They also provide satisfactory germination, protection from soil erosion and contribute to its nutritional value. The high percentage of grasses gives a good composition for grazing, while the high percentage of legumes in wood-pasture ecosystems contributes to a good conservation of soil fertility, as well as its progressive improvement [41,58]. Trees can also affect the seasonal distribution of pasture growth and nutritional quality, and this also affects the quantity of pasture consumed by the livestock $[1,59]$.

Other significant botanical families are present in wood-pastures (e.g., families of Asteraceae, Brassicaceae, Geraniaceae, Rosaceae, Lamiaceae) with their ecological value being indisputable, both in terms of the biodiversity and productivity of grassland ecosystems $[41,42,58]$. Furthermore, the role of trees and shrubs in forest ecosystems is very important and multifarious. The most important benefits that they provide are the follow- 
ing: (a) the production of wood for commercial and other purposes, (b) the production of fruits and resins, (c) the satisfaction of recreational needs (e.g., prey, landscape improvement, etc.), (d) soil stability, (e) the regulation of the hydrological function of catchment areas, (f) maintenance of the biodiversity and (g) contribution to the balance of forest ecosystems $[41,42,58]$.

\section{Grazing Management in Mediterranean Wood-Pastures}

\subsection{Role of Grazing in Plant Diversity of Mediterranean Landscapes}

The rangelands of the Mediterranean region play an important role both for the forage material production and the conservation of biodiversity in plant communities at the landscape level. These two management purposes are not conflicting but complementary when the management is based upon the knowledge of the effect of grazing on the ecology of these ecosystems [60]. Thirdwood [61] suggested that grazing by domestic animals is among the major causes of forest degradation, with goats being singled out for their predilection of woody forage. Tsoumis [62] also shared such ideas: "pastoral economy had a much greater influence on deforestation of the Mediterranean region than agricultural clearances." Moreover, overgrazing with or without wildfires has been reported as the most important agent of desertification in many parts of Greece [63-65].

Livestock grazing has extensively altered the composition and structure of grasslands throughout the world. Relatively predictable patterns of compositional and structural change with regard to long-term grazing have been substantiated in numerous perennial grasslands. Compositional changes most frequently involve the substitution of late-seral dominants by early or mid-seral species, while structural changes often involve the replacement of tallgrasses by mid- or shortgrasses [66]. Caldwell and others [67] mentioned that "less severely grazed species gain a competitive advantage by preempting resources previously used by the dominant species in the absence of grazing". Long-term selective grazing can differentially affect population persistence among various species and thereby modify community composition and structure. Grazing can change the structure of plant communities by reducing biomass, damaging sensitive species and promoting the development and establishment of resistant species [68,69]. The characteristics of the location are the most significant factors affecting the composition of species in the understory. Understory vegetation is key to the ecological changes that occur for several or dozens of years and the vegetation structure can show differences in disturbances that occur in the region [70,71]. It is widely known that natural disturbances affect the abundance, the process of succession and biodiversity in many plant communities [72-74]. Thus, the species composition and diversity can be used as indicators of the disorder in a region [75-78], such as for different light availability conditions, structures of vegetation $[79,80]$ and different moisture and soil fertility levels [81-84].

In Mediterranean ecosystems and particularly in Mediterranean shrublands, herbivores in vegetation mosaics vary in space and time. The leaves of different species vary in their physical and chemical characteristics, and therefore, in their attractiveness as food. Young leaves tend to be more tender and nutritious than more hard and dry mature leaves, which places restrictions on the food preferences of herbivores. Herbaceous plants begin their growth in early spring and age/die much earlier in the summer than bushy plants. Semi-deciduous shrubs lose some of their leaves during the summer period, while those of these shrubs that are dimorphic, have summer leaves with different morphology and chemical composition in the winter. Finally, evergreen shrubs and trees show significant differences in several characteristics of the leaf. The nutritional value of plant tissue for the herbivore or otherwise the "food quality" is regarded as a very decisive factor on the pressure of grazing, and therefore the damage that plants receive. The nutritional value consists of a number of parameters, such as the amount of nitrogen and the water contained in the plant tissue, the species, the molarity of defensiveand tissue hardness $[85,86]$.

It is important to mention the contradictory position: that limited grazing seems to lead to the extinction of grazing-prone species or to flammable biomass piling up [87]. Nowa- 
days, because of the drastic reduction in human activities in the region, including grazing due to urban sprawl, extensive wildfires occur, especially in southern European countries.

\subsection{The importance of Fungi in Ecosystem Processes}

Fungi are widely distributed and comprise a heterogeneous group (taxonomically and phyllogenically) which are found in both terrestrial and aquatic ecosystems and under different-sometimes even extreme-environments [88]. Fungi coexist along with other organisms in an ecosystem; the actual number and the ecological role of fungal species existing in the different ecosystems is extremely difficult to assess [89-91]. Fungi develop dynamic interactions with a wide range of other organisms (plants/trees, animals, other microorganisms) and with the environment (abiotic factors), regulating vital ecosystem processes, among those being nutrient availability and decomposition [90]. According to Dighton [90], fungi are intimately involved in major ecosystem services and functions which relate to: (i) primary production by making nutrients available for plant growth and/or enhancing nutrient uptake in the rhizosphere; (ii) secondary production by providing food for both vertebrate and invertebrate animals and through other fungal/faunal interactions; (iii) pathogenic effects (parasites) on plant/tree and animal populations and communities; and (iv) interactions with human activities (pollution, built environment).

Despite the fact that fungi act as ecosystem engineers in many habitats, they only started to receive attention as essential components of natural ecosystems during the last few decades [86]. Only recently, ecologists realized the highly important influence of the interactions occurring among plants/trees (at both root and aerial level), animals and fungi in ecosystem functioning and biodiversity maintenance $[88,91,92]$. Moreover, some fungal species can develop mutualistic associations with other organisms (e.g., mycorrhizal relationships with trees in forest ecosystems) or they may act as natural enemies (biocontrol agents) and prevent attacks from pathogens and herbivores [91]. Fungi also provide services for other organisms (including mammals, plants, insects and other microorganisms), operating as direct or indirect food resources for many of them [91]; additionally, they are often critically involved in microhabitat formation (e.g., tree cavities), which is a prerequisite for the maintenance of several birds, mammals, arthropods and epiphytes [91,92].

However, degradation, climate change, the loss and fragmentation of natural habitats and the deposition of nitrogen and other pollutants comprise threats for fungal biodiversity [91,93]. The state of fungal biodiversity, like that of plants, animals and birds, should be recorded in order to design and prioritize management and/or conservation measures based on fungal population status in specific habitats. Threatened fungal species can only be identified if their ecology and distribution are well understood [94]. This information is not available for mycobiota of the Mediterranean area [94]; instead, in many central and northern European countries (UK, Sweden, Finland, Norway) fungal red lists are already widely used and action plans have been launched in order to protect specific fungal habitats and species [91].

During the last few decades, many countries have developed conservation programs with direct measures on habitat level and they are not so much focused on specific species [91]. However, many unspotted or unknown organisms (especially microorganisms) are often ignored in those conservation programs, whilst the organisms involved in a particular habitat should be considered together in order to identify their interactions and prioritize action measures at the species level. In terms of fungal conservation, it is very important to provide more insight into the ecology of fungal species in their preferential environments (substrate, climatic range, altitude, etc.), assess indicator species, population dynamics and their periodicity and identify their role in the ecological processes of their habitat. 


\subsubsection{The Dynamics of Fungal Communities in Mediterranean Wood-Pasture Landscapes}

Wood-pastures comprise ancient places of natural and historical heritages for many Mediterranean countries. The management of wood-pastures is critical for biodiversity maintenance. However, as mentioned in previous sections, during the last few decades, considerable decline has been observed in many of those biotopes; this decline is causing a threat to many species inhabiting wood-pastures, including fungi. Often, fungi comprise very good indicators of traditional rural biotopes [95]; however, the available data and information of the occurrence, distribution, ecology and conservation biology of fungal species, the interactions with their habitat and environmental factors in wood-pastures in the Mediterranean region, are scarce and segmented [96].

The factors regulating fungal diversity are relatively poorly understood $[97,98]$. Ecosystems with a Mediterranean climate are considered to exhibit a relatively higher fungal biodiversity $[98,99]$ with plant/tree host diversity, density, host demography, community composition of a particular habitat (flora, fauna, micoorganisms), local effects (e.g., natural canopy gaps, microclimate development), soil composition, texture, altitude, and human innervations (e.g., type of applied management) being some of the most important factors affecting fungal diversity in a particular habitat [100].

Some studies focused on macrofungi (fungi with visible fruit bodies) in forest ecosystems, but only few of those were carried out in Mediterranean environments, specifically in France, Italy and Spain [98,101,102]. Richard et al. [100] studied the diversity and the fruiting patterns of ectomycorrhizal and saprobic fungi in Quercus ilex dominating in Mediterranean forest. Few surveys have been carried out in Italian woodlands of $Q$. ilex, $Q$. pubescens, Q. cerris and recorded macrofungal species in detailed lists [103-110]. Meanwhile, in Andalusia, communities of macrofungi were studied in Q. suber and Q. ilex forests [111]. A more integrated study was carried in Liguria stands of $Q$. rotundifolia (formely known as Q. ilex) in order to identify fungal species, evaluate fungal communities and determine the principal environmental gradients which shape the fungal communities in the sampled areas [98].

The above-mentioned studies provided some basic but important insights on the distribution, ecology and phenology of fruiting in many fungal species; however, some species are extremely rare, they do not produce visible fruit structures or they fruit only at certain time points and under very specific conditions; therefore, the detection and monitoring of such species is not an easy task [112]. In many cases, human activities impact fungal diversity and communities over various scales in relation to vegetation [98]. The topic of studying fungal biodiversity and conservation biology in relation to influences by human activities (including invasions by alien fungal species), land-use change and climate change is becoming increasingly important and has not been addressed yet in Mediterranean wood-pasture ecosystems. Wood-pastures comprise a typical example of an ecosystem where tight interactions among human activities and various other organisms are observed. The accurate recording of fungal species distribution in time and space and their population dynamics under the various environmental conditions is extremely important and absolutely necessary in order to decode the keystone role of certain species in certain ecological processes, prioritize management measures and improve the sustainability of their habitats. In the case of wood-pastures, studies on the effects of grazing on plants and fungal communities would aid the development of national recording schemes (for vegetation and fungi) for Mediterranean countries. Additionally, this would allow us to identify sites with critical biodiversity stages due to overgrazing or changes in land use (e.g., abandonment), to specify the criteria for sites of major conservation importance, to design appropriate action plans for priority sites and to monitor the applied management practices in order to enhance the sustainability of those areas. On the other hand, the quality of animal products is highly affected by the type of vegetation grazed. Therefore, this type of study can have a binary role if correlated with the nutritional effects of the grazed vegetation on the quality of the animal products; grazing practices can then be 
introduced so as to improve the quality of the produced animal products and increase the added value of those products.

\subsubsection{The Effect of Grazing on Fungal Biodiversity in Mediterranean Wood-Pastures}

Grazing is considered a management strategy which can be used as a useful conservation tool with the concurrent improvement of rural sustainability [113]. Grazing pressure in habitat can influence both animal performance (productive responses, economic output) and the biodiversity of flora and fauna (including microorganisms) [113]; on the other hand, the types of grazing animals (species, breed, age, physiological status), stocking rate and available vegetation in terms of quantity and quality determine the grazing pressure in a particular habitat [113]. Consequently, grazing effects depend on many factors and the development of an appropriate or optimal grazing system should be based on specific management objectives for each habitat or landscape [113]. It is assumed that a mosaic of vegetation is created through grazing, which in turn favors the creation of habitat patches for species living in these biotopes [114]. Moreover, mixed grazing is stated to generate greater habitat heterogenicity compared to monospecific grazing; this leads to the formation of a wider range of available niches (for a diversity of organisms) and microclimatic conditions [113]. The successional dynamics of vegetation is therefore linked with animal grazing and considerably affects habitat biodiversity [112]. One of the major impacts of grazing to the habitat is that the amount of nutrients and litter in the soil is decreased [115,116]; this greatly benefits the growth of many fungal species [117]. Other impacts which favor growth conditions for fungi are related to the changes in the amount of light at ground level (solar radiation), soil temperature, moisture and pH [116-118].

Despite the major importance of fungi in the biodiversity of Mediterranean woodpasture biotopes, the effects of the grazing pressure on the fungal diversity have been neglected so far. To the best of our knowledge, there are no concrete data on the interaction between livestock grazing and fungal diversity in Mediterranean wood-pastures. Most of the research work has focused on the effects of grazing to plant diversity so far. Some general and scarce information on the effects of grazing on fungal diversity were mainly based on the previous knowledge regarding grazing-plant interaction [119-122]. Many studies have pointed out that there is a congruence between plant and fungal communities [123-126]. The diversity of tree species is often linked with higher macrofungi diversity, mainly because of the development of diverse available substrates which are created for macrofungi growth [127]. According to Arnolds [128], reduced litter in the soil benefits the development of most mychorrhizal fungal species. However, according to Zervakis and Venturella [96], mycorrhizal fungi were variably affected by grazing; the effects were mainly correlated to the degree of grazing and the yearly variability in precipitation. A strong but localized effect was highlighted between canopy gaps and the fruiting of saprobic and ectomycorrhizal (symbiotic) fungi in old-growth Q. ilex Mediterranean forest [97-100]; canopy gaps allow direct light to reach the forest floor, which in turn stimulates changes in soil abiotic conditions (temperature, soil nutrients, moisture) and drive physiological and metabolic activities of the fungal symbionts and other organisms [90,93]. A significant relationship between macrofungi species diversity and plants was recorded in areas which are not affected by intense glaciation [129].

In order to assess the diversity of fungi in Mediterranean wood-pastures, we need to design and develop appropriate management practices for their conservation, which are necessary to investigate topics such as: (i) the differences in the species richness and their population dynamics between grazed and ungrazed wood-pastures; (ii) the effect of grazing pressure (intensive, intermediate, ungrazed) in relation to the fungal community composition; (iii) the interrelationships between the different trophic levels (plant/trees-animals-fungi); if the different fungal functional (trophic) groups are equally represented in grazed and ungrazed wood-pastures; (iv) the indirect effects of grazing on fungal growth (soil, temperature, light, $\mathrm{pH}$, etc.). Such studies are labor intensive and time consuming (involving years of seasonal observations) and require specialist knowledge. 
These conventional methods for surveying fungi richness and abundance are limited by taxonomic identification, may cause the disturbance or destruction of habitats, and may rely on methods in which it is difficult to detect small or elusive species, thus making estimates for entire communities impossible [130]. However, more recently, advances in environmental DNA (eDNA) metabarcoding have enabled the broad application of this method in multi-kingdom biodiversity monitoring; for reviews, see, e.g., [130,131]. eDNA can complement traditional methods by targeting different species, sampling greater diversity, and increasing taxonomic resolution [132]. Additionally, it has useful applications in detecting the first occurrences of invasive species, the continued presence of native species thought to be extinct or otherwise threatened, and other elusive species occurring in low densities that would be difficult to detect by traditional means. Nevertheless, before being applied to fungal communities in Mediterranean areas, it is important to take into consideration the necessity of selecting different appropriate substrates to broadly capture all biota present in the ecosystem [133]. Therefore, preliminary studies are needed to optimize this tool for Mediterranean terrestrial ecosystems. The use of the eDNA tool for the detection and monitoring of a specific species or group of organisms can be incorporated alongside traditional monitoring and can unravel different aspects of management in Mediterranean wood-pastures. For instance, nematode communities are among the most valuable communities in soil in regard to understanding nutrient dynamics. It is well known that nematodes play an important role in determining soil functioning [134], since a significant part of nutrient interchange in soils takes place because of the activity of microbial-feeding nematodes [135]. Free-living nematodes can serve as soil indicators because of their high species richness and abundance. Nematodes are very adaptable and common in almost any soil type [136] and they conform to the general characteristics required of a bio-indicator [137]. Soil nematode communities have the potential to provide insights into many ecological studies such as the effects of grazing activity. In grazing systems, grazing intensity and timing should be planned well in order to adopt sustainable grazing management and increase soil organic matter and encourage soil structure [138]. It is well known that grazing results in a more structured nematode community [139]. Unfortunately, there is a limited number of studies that evaluate these effects on free-living nematodes. Li et al. [140] showed that heavy grazing resulted in reduced organic matter and that the grazing intensity influenced the number of nematodes overall [141]. In addition, the Maturity Index of nematodes (MI) was found to be significantly influenced by the grazing strategy. A considerable number of studies have shown that there is a significantly positive effect of grazing on nematode communities in different types of grasslands [141,142]. On the other hand, the abundance of total nematode community was found to be significantly lower on seriously disturbed sites [142]. However, in 1988, it was shown that the exclusion of grazing in areas with a long history of grazing can be considered as a disturbance, meaning a more diverse community of nematodes can be maintained under continuous moderate grazing [143]. Enhancing research on nematode communities and links with the grazing system is an important step towards understanding soil ecosystems under different grazing management strategies. To this end, studies are needed to further evaluate the use of nematode communities under different grazing strategies.

\subsection{Effect of Wood Land Grazing on Ruminants}

In the past, woody species were considered poor feed for animals and efforts were made to control or eradicate them from grasslands. Over the last 25-30 years, this attitude has changed, and substantial research has been performed to show that woody species are important forage resources in the Mediterranean areas of Europe. Animal production in this part of Europe is constrained by the rugged and highly fragmented landscape, the rich but variable vegetation and complex land-use systems [144]. The most important factor that affects herbage production and animal performance is the Mediterranean climate $[145,146]$. Woody species are both spontaneous and cultivated in the Mediterranean areas of Europe and constitute indispensable feed resources for livestock during the whole 
year, but especially during the long and dry summer period. Woody plant communities, such as shrublands and woodlands, are much more widespread in the Mediterranean areas of Europe than grasslands. Different livestock species have been used as a control tool for the Mediterranean understory, with goats being the most widely used animal for this purpose, due to their more selective nature and their ability to tolerate many secondary compounds [147]. Natural woody communities can be grazed directly by livestock, with shrublands being the most appropriate feed resources for goats [147]. Goats are most appropriate to utilize the high fiber, low $\mathrm{N}$ forage produced on shrublands and woodlands $[148,149]$. In the extensive livestock production systems of Mediterranean goat and sheep husbandry, both depend on browse and herbage produced by wooded rangelands during certain times of the year to satisfy their needs for nutrients [149-158].

Browse plants (leaves and twigs) (e.g., Quercus coccifera, Cistus incanus, Rubus sp.) and herbaceous plants (e.g., Festuca sp., Dactylis glomerata, Trifolium sp., Medicago sp. and Vicia sp.) are important forage sources for goats throughout the year and for sheep during the dry periods when herbage is limited [156]. The herbaceous component contributes more than $50 \%$ of the goat's diets during spring when herbs are green. During the rest of the year, goats select huge amounts of browse $(>60 \%)$. Leaves of all forage species contribute more than $70 \%$ during all periods, while twigs of shrubs and stems from herbaceous species are low but constant throughout the year [159]. Studies by Dini [160], Platis and Papanastasis [161], Papachristou and Papanastasis [162], Papachristou [154] and Ainalis et al. [163] suggested that during summer, when herbaceous plants are dormant and herbage is of low quality and availability, forage of woody vegetation has to meet nutritional requirements for the grazing animals [163-165]. Deciduous woody fodder species are an effective supplement to low-quality forage and significantly increase crude protein intake. Therefore, browse-based protein supplementation seems to be a practical means of maintaining the body weight of goats grazing on low-quality forage (e.g., Mediterranean kermes oak shrublands) during the summer period [155] Moreover, the heterogeneous forage environment of wooded rangelands offers conditions that may favor a very fast intake for small ruminants that discriminate between forage materials, while at the same time maintaining an intake rate higher than that observed during their meal [166,167].

In the wet months, goats consume the largely defenseless undergrowth of herbaceous species, whereas in the dry months when herbs are dry or no longer available, they are left with only the kermes oak with its physical and chemical defenses [156]. The fact that plant defenses are so widespread and often herbivores have no choice but to consume plants with defenses suggests that they are well aware of the consequences of eating most plant species [168]. This latter point gives reasons to think that sheep and goats have significant knowledge of the plant species and their defenses in their home rangeland. In relation to plant defenses, animals avoid defenses where possible, and if not possible, select the plant with the least effective defense. This may be simple and indeed obvious, but it enables animals to react quickly to changes in habitat composition across seasons.

Overall, the positive outcome from grazing in silvopastoral systems is arriving from increased production and animal welfare [169]. In order to further increase the beneficial role of grazing in animal nutrition, the development of more adaptive conservation and land management systems is required. Therefore, the traditional knowledge and local familiarity of herders is essential $[170,171]$.

\section{Products and PDO}

Over the years, the impact of the environment and human intervention gave rise to various characteristics of animal products unique for each region. An important part of the specificity of the products owes its existence to the utilization of mountain pastures. The special geomorphological characteristics and the biodiversity that characterizes these specific areas, as well as the number of agricultural improvements (fertilization, grazing management) directly affect the characteristics of the various dairy products, but also those of meat [172]. 
The specialized metabolites of the dicots that originate in mountainous grazing areas, such as terpenoids or phenolic compounds, have the ability to indirectly affect the fatty acid profile of animal products through the animal's digestive system and metabolic process. The variability of breeds and needs of the animals raised in these areas, as well as the management system of the mountain pastures, also influence the choice of grazing and the phenology of the grazed pastures. It is essential in order for the animal products to reflect the uniqueness and diversity of the area where they originate to consider the above factors when corrective measures are intended [172].

In Europe, many agricultural (14\%) and livestock (18\%) enterprises are located in mountainous areas and host $20.4 \%$ of sheep and $46.8 \%$ of goat EU population. Those animals provide $32.0 \%$ of the total goat and ewe milk and $23.4 \%$ of the sheep meat [173]. These data highlight the quantifiable importance of mountain productivities for the ruminant livestock sector that is also involved in preserving the landscape and the rural social network.

Traditionally, sheep grazed local grassland regarded as less-favored pastures. In order for producers to overcome the constraints of distant areas, they had to promote milk production and thus increase the feed purchases and inputs in farms. Until the 2000s, the intensification of forage harvesting was used as an efficient alternative to grazing. Since 2000, the PDO specifications included new requirements that forced farmers to utilize forages. As an example, grazing ewes should be fed with forage coming for $75 \%$ from the PDO area and ewes should graze two or three months during the grazing period [174].

To produce a traditional food product, the suckling lambs are fed exclusively on maternal milk from birth to slaughter (average age of 40 days and body weight of 10-12 kg). However, grazing pasture is an interesting alternative [175] because ewes and lambs have good performance and the use of natural resources is increased.

- Meat

Ruminants grazing on mesophilic grasslands (MGs) can utilize forage of higher palatability, nutritive value and concentration of originators (e.g., C18:3 n3) for the synthesis of beneficial fatty acids (FAs) (e.g., rumenic acid and omega-3 FA) in dairy and meat products. In order to obtain animal products richer in nutraceutical compounds, agropastoral practices that promote MG formation, such as intensive management and soils with higher moisture content, are essential [176]. Research demonstrates that the present practice for changing intensive to free grazing systems affects meat characteristics. One of the most pretentious characteristics is the color, the most important attribute taken into account by end users in their purchase choice [174]. The subcutaneous fat of lambs from pastures had higher yellowness $\left(b^{*}\right)$, connected with the existence of carotenoids, flavonoids and a-tocopherol in their food intake [177], than those from concentrate-based diets. Likewise, fat from suckling lambs whose mothers grazed had greater yellowness and redness than that from lambs whose mothers were fed hay [178]. This probably resulted from the low grass consumption by the lamb [179] in addition to the intake of milk carotenoids [180]. Grass-fed lambs may provide meat with a low degree of fat and red meat color [181]. The meat quality of lamb raised exclusively on maternal milk can be improved with the addition of grass to the diet [182], due to the high quality of milk from grazing sheep [183]. The amount of linolenic acid in the intramuscular fat of lambs fed with milk from grass-fed ewes was higher. The feeding scheme related to birth and lactation affects the milk FA profile [178]. The fatty acids that are mainly affected by grazing are CLA, C18:1t11 and PUFA, n-6/n-3 ratio, with a positive effect on human health. Grazing during the animal's dry period, regardless of post-partum feeding, can change the FA composition, increasing the CLA content in meat. The degree of the increase in CLA, C18:1t11 and PUFA n-3 of grass-based diets in comparison to concentrated diets depends on the maturity, diversity and conservation of the forage [184]. 


\section{- Cheese}

With regard to dairy products and especially cheese, their characteristics are the result of the interaction of livestock with the environment. As a fermentation product, the rumen microflora is the one that initially transforms the organoleptic characteristics of the product produced. This microbial community is directly affected by the mobility of the animals and the complexity of the vegetation used as fodder [172].

Practical knowledge gained by farmhouse cheesemakers is associated with the influence of specific vegetal communities found in mountain grasslands on cheese organoleptic properties. Those distinctive characteristics are gained in mountain conditions where vegetation gradients and complementary plant mosaics are met even within similar grassland according to variable micro-climates, soil and agricultural practices [172].

Pastures are poor in terpenoids, while plant compounds are rich and extensively variable in forbes [185]. These compounds are responsible for the differentiation of the scents and aromas in cheese and vary according to the forages fed to the livestock $[186,187]$. Several studies concluded that terpenoids can easily move from herbage to milk [188], while others highlighted differences in milk terpenoids composition according to the botanical composition of grass or hay $[189,190]$.

During the sensory analysis of milk, the concentration of essential oils rich in terpenoids should be ten times higher than those in milk derived from grazing animals, even on extremely bio-differentiated pastures, in order to reach the threshold for sensory perception reported by Tornambe et al. [191]. Additional milk elements, such as polyphenols, are other vegetable metabolites that can be shifted to milk [192]. The fatty acid profile in milk can also affect cheese sensory characteristics [193]. A greater concentration of PUFA in milk can lead to a poorer fat melting point, with a subsequently less firm, softer and melting texture of cheese [194]. When a considerable amount of PUFA is oxidized, large amounts of odor active compounds during ripening can also generated. This procedure can have an important effect on cheese scent and aromas [195]. Cheese appearance does not remain unaffected from the composition of the fatty acids in milk [196], probably because during pressing, the PUFA-rich fat creates oil and therefore contributes to the growth of molds and yeasts.

- Success stories of mountain ruminant farming

The long-term feasibility and attractiveness of mountain livestock farming mostly relies on higher farm gate prices for productions. Although the differences in the milk and meat sector between mountain and intensive farming are still in favor of the first, many different patterns can still be found in different sectors or regions. Successful stories of certain mountain areas depend on the enthusiasm and commitment of local stakeholders that inspire and introduce a variety of differentiated food products [193] that contribute to an added-value food chain. Elements such as tradition and local know-how of agricultural practices can be proven as valuable opportunities. The value of the interactions between livestock products and local history, culture, tourism, handcraft and gastronomy can initiate the creation of a unique product, also known as a "basket of goods" [197]. This practice can develop an extensive added-value output utilized from certain geographically limited regions. There are unique success stories that rely on the differentiation of a terroir product correctly identified and protected by a Geographical Indication. The popular models of Beaufort, Comte and Laguiole are related to the respective mountain areas in France or the Aosta Valley in Italy. These examples appear to be replicable in similar mountain areas where farm density remains vital [198].

\section{Conclusions}

The lack of prior research on the interactions among different trophic levels (plants/trees, animals, microorganisms) and environmental factors in Mediterranean wood-pastures highlights an important opportunity for future study of the biodiversity of those ecosystems and the exploitation of opportunities for the rural development of those ecosystems. 
In order to set up the basis for appropriate management practices in Mediterranean wood-pastures, it is absolutely necessary to conduct future studies on this topic; the studies should be thoroughly focused on the interactions among the different trophic levels (plant/trees, animals, microorganisms) and on the recording of critical species which relate either to important ecosystem processes or are important for rural development (economically important plant, fungal, animal species) or both. In this way, it will be possible to enhance sustainability in those biotopes, value plant and fungal bioindicators, assess the effects of grazing on animal welfare and/or increase the quality of the animal products produced and therefore increase marketable (added) value. Integrated studies which combine multi-level ecological research are essential in order to identify regional and/or national needs in terms of biodiversity, genetic resources, sustainable rural development and conservation policies. eDNA is a promising tool which can supplement traditional monitoring and contribute to assessing multi-level trophic interactions, increasing detailed knowledge on biodiversity and the species-specific occurrence and abundance of Mediterranean wood-pastures. The opportunities to harness higher-level interdependencies and interactions between the biodiversity of soil, plants, above and below-ground animals, and the environment are immense, and offer great potential if they can be understood, directed and actively managed.

Author Contributions: Conceptualization, E.T., A.D.S., E.K. and K.M.; methodology, E.T. and A.D.S.; formal analysis, E.T., A.D.S., S.S.S., E.K., S.K. and K.M.; investigation, E.T., A.D.S., S.S.S., E.K., S.K. and K.M., resources, E.T. and A.D.S.; data curation, E.T., A.D.S., E.K. and K.M.; writing-original draft preparation, E.T., A.D.S., S.S.S., E.K., S.K. and K.M.; writing-review and editing, E.T., A.D.S., S.S.S., E.K., S.K. and K.M.; visualization, A.D.S.; supervision, E.T., A.D.S., E.K. and K.M. All authors have read and agreed to the published version of the manuscript.

Funding: This research received no external funding.

Institutional Review Board Statement: Not applicable.

Informed Consent Statement: Not applicable.

Data Availability Statement: Data available on request due to privacy restrictions.

Acknowledgments: The authors wish to thank all researchers who had articles published with regard to the dynamic role and importance of multi-kingdom communities in Mediterranean wood-pastures.

Conflicts of Interest: The authors declare no conflict of interest.

\section{References}

1. De Jalón, S.G.; Graves, A.; Moreno, G.; Palma, J.H.N.; Crous-Durán, J.; Kay, S.; Burgess, P.J. Forage-SAFE: A Model for Assessing the Impact of Tree Cover on Wood Pasture Profitability. Ecol. Model. 2018, 372, 24-32. [CrossRef]

2. Plieninger, T.; Levers, C.; Mantel, M.; Costa, A.; Schaich, H.; Kuemmerle, T. Patterns and drivers of scattered tree loss in agricultural landscapes: Orchard meadows in Germany (1968-2009). PLoS ONE 2015, 10, e0126178. [CrossRef]

3. Solomou, A.D.; Sfougaris, A. Predicting Woody Plant Diversity as Key Component of Ecosystems: A Case Study in Central Greece. IJAEIS 2019, 10, 1-20. [CrossRef]

4. Solomou, A.D.; Sfougaris, A. Contribution of Agro-Environmental Factors to Yield and Plant Diversity of Olive Grove Ecosystems (Olea Europaea L.) in the Mediterranean Landscape. Agronomy 2021, 11, 161. [CrossRef]

5. Plieninger, T.; Höchtl, F.; Spek, T. Traditional land-use and nature conservation in European rural landscapes. Environ. Sci. Policy 2006, 9, 317-321. [CrossRef]

6. Stoate, C.; Báldi, A.; Beja, P.; Boatman, N.D.; Herzon, I.; van Doorn, A.; de Snoo, G.R.; Rakosy, L.; Ramwell, C. Ecological impacts of early 21st century agricultural change in Europe-A review. J. Environ. Manag. 2009, 91, 22-46. [CrossRef] [PubMed]

7. Sollen-Norrlin, M.; Ghaley, B.B.; Rintoul, N.L.J. Agroforestry Benefits and Challenges for Adoption in Europe and Beyond. Sustainability 2020, 12, 7001. [CrossRef]

8. Hartel, T.; Plieninger, T. European Wood-Pastures in Transition Asocial-Ecological Approach; Hartel, T., Plieninger, T., Eds.; Fish Books Routledge: London, UK; New York, NY, USA, 2014.

9. Garbarino, M.; Lingua, E.; Subirà, M.M.; Motta, R. The larch wood pasture: Structure and dynamics of a cultural landscape. Eur. J. For. Res. 2011, 130, 491-502. [CrossRef]

10. Bergmeier, E.; Petermann, J.; Schröder, E. Geobotanical survey of wood-pasture habitats in Europe: Diversity, threats and conservation. Biodivers. Conserv. 2010, 19, 2995-3014. [CrossRef] 
11. Ferraz-de-Oliveira, M.I.; Azeda, C.; Pinto-Correia, T. Management of Montados and Dehesas for High Nature Value: An Interdisciplinary Pathway. Agrofor. Syst. 2016, 90, 1-6. [CrossRef]

12. Bernues, A.; Rodríguez-Ortega, T.; Ripoll-Bosch, R.; Alfnes, F. Socio-Cultural and Economic Valuation of Ecosystem Services Provided by Mediterranean Mountain Agroecosystems. PLoS ONE 2014, 9, e102479. [CrossRef] [PubMed]

13. da Clara, M.I.E.; de Almeida Ribeiro, N.M.C. Decline of Mediterranean Oak Trees and Its Association with Phytophthora Cinnamomi: A Review. Eur. J. For. 2013, 132, 411-432. [CrossRef]

14. Charvalas, G.; Solomou, A.D.; Giannoulis, K.D.; Skoufogianni, E.; Bartzialis, D.; Emmanouil, C.; Danalatos, N.G. Determination of Heavy Metals in the Territory of Contaminated Areas of Greece and Their Restoration through Hyperaccumulators. Environ. Sci. Pollut. Res. 2021, 28, 3858-3863. [CrossRef] [PubMed]

15. Di Castri, F. Mediterranean-type shrublands of the world. In Ecosystems of the World: Mediterranean-Type Shrublands; Di Castri, F., Goodall, D.W., Specht, L.R., Eds.; Elsevier: Amsterdam, The Netherlands, 1981.

16. Hobbs, R.J.; Richardson, D.M.; Davis, G.W. Mediterranean-type ecosystems: Opportunities and constraints for studying the function of biodiversity. In Mediterranean Type Ecosystems: The Function of Biodiversity; Davis, G.W., Richardson, D.M., Eds.; Springer: Berlin, Germany, 1995.

17. Orshan, G. Approaches to the definition of Mediterranean growth forms. In Mediterranean-Type Ecosystems: The Role of Nutrients; Kruger, F.J., Mitchell, D.T., Jarvis, J.U.M., Eds.; Springer: Berlin, Germany, 1983.

18. Aschmann, H. Distribution and peculiarity of Mediterranean ecosystems. In Mediterranean Type Ecosystems; Di Castri, F., Mooney, H., Eds.; Chapman \& Hall: London, UK, 1973; pp. 11-19.

19. Polade, S.D.; Gershunov, A.; Cayan, D.R.; Dettinger, M.D.; Pierce, D.W. Precipitation in a Warming World: Assessing Projected Hydro-Climate Changes in California and Other Mediterranean Climate Regions. Sci. Rep. 2017, 7, 1-10. [CrossRef]

20. Vamvaka, N. Mediterranean Type Ecosystems. Bachelor's Thesis, Department of Environment, University of Aegean, Mytilene, Greece, 2004.

21. Kazakou, E. The Effect of Ecological Factors Key to Development of Vegetation Mediterranean Ecosystems. Bachelor's Thesis, Environment Section, University of the Aegean, Mytilene, Greece, 2001.

22. Raposo, M.A.; Gomes, C.J.P.; Nunes, L.J. Selective Shrub Management to Preserve Mediterranean Forests and Reduce the Risk of Fire: The Case of Mainland Portugal. Fire 2020, 3, 65. [CrossRef]

23. Blondel, J.; Aronson, J. Biodiversity and ecosystem function in the Mediterranean basin: Human and non-human determinants. In Mediterranean-Type Ecosystems: The Function of Biodiversity; Davis, G.W., Richardson, D.M., Eds.; Springer: Berlin, Germany, 1995.

24. Mittermeier, R.A.; Gil, P.R.; Hoffmann, M.; Pilgrim, J.; Brooks, T.; Mittermeier, C.G.; Lamoreux, J.; Da Fonseca, G.A.B. Hotspots Revisited: Earth's Biologically Richest and Most Endangered Terrestrial Ecoregions; University of Chicago Press: Chicago, IL, USA, 2004.

25. Myers, N.; Mittermeier, R.A.; Mittermeier, C.G.; da Fonseca, G.A.B.; Kent, J. Biodiversity hotspots for conservation priorities. Nature 2000, 403, 853-858. [CrossRef] [PubMed]

26. Kark, S.; Levin, N.; Grantham, H.; Possingham, H. Between-country collaboration and consideration of costs increase conservation planning efficiency in the Mediterranean Basin. Proc. Nat. Acad. Sci. USA 2009, 106, 15360-15365. [CrossRef]

27. Naveh, Z.; Dan, J. The human degradation of Mediterranean landscape in Israel. In Mediterranean Type Ecosystems, Origin and Structures; di Castri, F., Mooney, H.A., Eds.; Springer: Berlin/Heidelberg, Germany, 1973; pp. 373-390.

28. Turner, M.G. Landscape ecology: The effect of pattern on process. Annu. Rev. Ecol. Syst. 1989, 20, 171-197. [CrossRef]

29. Levin, S.A. The problem of pattern and scale in ecology. Ecology 1992, 73, 1943-1967. [CrossRef]

30. Peterson, G.D. Contagious disturbance, ecological memory, and the emergence of landscape pattern. Ecosystems 2002, 5, 239-338. [CrossRef]

31. Lieberman, D.; Lieberman, M.; Hartshorn, G.S.; Peralta, R. Growth rates and age-size relationships of tropical wet forest trees in Costa Rica. J. Trop. Ecol. 1985, 1, 97-109. [CrossRef]

32. Aquino, F.G.; Oliveira, M.C.; Schiavini, I.; Ribeiro, J.F. Dinâmica de populações de Anadenanthera macrocarpa e Acacia glomerosa em mata seca semidecídua na Estação Ecológica do Panga (Uberlândia-MG). Boletim Herbário Ezechias Paulo Heringer 1999, 4, 90-102.

33. Naveh, Z. The evolutionary significance of fire in the Mediterranean region. Vegetatio 1975, 29, 199-208. [CrossRef]

34. Oakley, K.P. Fire as a Palaeolithic tool and weapon. Proc. Prehist. Soc. 1955, 21, 36-47. [CrossRef]

35. Perlés, C. Préhistoire du Feu; Masson: París, France, 1977.

36. Trabaud, L. Fire and survival traits of plants. In The Role of Fire in Ecological Systems; Trabaud, L., Ed.; SPB Acedemic Publishing: The Hague, The Netherlands, 1987; pp. 91-95.

37. Stapert, D.; Johansen, L. Making fire in the Stone Age: Flint and pyrite. Geol. Mijnb. 1999, 78, 147-164. [CrossRef]

38. Farina, A. Principles and Methods in Landscape Ecology; Chapman \& Hall: London, UK, 1998.

39. Moreira, A.; Rego, F.C.; Ferreira, P.G. Temporal (1958-1995) pattern of change in a cultural landscape of northwestern Portugal: Implications for fire occurrence. Landscape Ecol. 2001, 16, 557-567. [CrossRef]

40. Pausas, J.G.; Ramos, J.I. Landscape pattern, fire regime and vegetation dynamics-A modelling approach. In Ecology, Conservation and Management of Mediterranean Climate Ecosystems of the World, Proceedings of the MEDECOS 10th International Conference, Rhodes, Greece; Arianoutsou, M., Papanastasis, V.P., Eds.; Millpress: Rotterdam, The Netherlands, 2004.

41. Sarlis, G.P. Improvement and Management of Natural Pastures Part A; Stamoulis Press: Athens, Greece, 1998. 
42. Tsibrakou, K. The Production of Viscose Material of Meadow "Kostilata" Theodorian Artas; Department of Agriculture and Food Technology: Arta, Greece, 2017.

43. Arianoutsou, M. Biological Activity after Fire in a Phryganic Ecosystem. Ph.D. Thesis, University of Thessaloniki, Thessaloniki, Greece, 1979. (In Greek with an English Summary).

44. Johnson, E.A. Fire and Vegetation Dynamics: Studies from the North American Boreal Forest; Cambridge University Press: Cambridge, $\mathrm{UK}, 1992$.

45. Zedler, P.H.; Gautier, C.R.; McMaster, G.S. Vegetation change in response to extreme events: The effect of a short interval between fires in California chaparral and coastal scrub. Ecology 1983, 64, 809-818. [CrossRef]

46. DфAntonio, C.M.; Vitousek, P.M. Biological invasions by exotic grasses, the grass/fire cycle and global change. Annu. Rev. Ecol. Syst. 1992, 23, 63-87. [CrossRef]

47. Lloret, F.; Pausas, J.G.; Vila, M. Response of Mediterranean plant species to different fire regimes in Garraf Natural Park (Catalonia, Spain): Field observations and modelling predictions. Plant Ecol. 2003, 167, 223-235. [CrossRef]

48. Arianoutsou, M. Annual Report to the General Secretariat for Research and Technology Research Pened. In Program Entitled: Assessment of Mediterranean Ecosystems Desertification Trends as a Result of the Action of Fire; National and Kapodistrian University of Athens: Athens, Greece, 1998; p. 114.

49. Trabaud, L. Post-fire community dynamics in the Mediterranean Basin. In The Role of Fire in Mediterranean-Type Ecosystems; Moreno, J.M., Oechel, W.C., Eds.; Ecological Studies 107; Springer: New York, NY, USA, 1994; pp. 1-15.

50. Kazanis, D.; Arianoutsou, İ. Vegetation composition in a post-fire successional gradient of Pinus halepensis forests of Attica, Greece. Int. J. Wildland Fire 1996, 6, 83-91. [CrossRef]

51. Arianoutsou, M. Aspects of demography in post-fire plant communities of Greece. In Landscape Degradation and Biodiversity in Mediterranean Type Ecosystems; Rundel, P.W., Montenegro, G., Jaksic, F., Eds.; Ecological Studies 136; Springer: Berlin/Heidelberg, Germany, 1998; pp. 273-295.

52. Arianoutsou, M.; Neéman, G. Post-fire regeneration of natural Pinus halepensis forests in the East Mediterranean Basin. In Ecology, Biogeography and Management of Mediterranean Pine Forests; Neéman, G., Trabaud, L., Eds.; Backhuys Publishers: Leiden, The Netherlands, 2000; pp. 269-290.

53. Papanastasis, V.P. Fire ecology and management of phrygana communities in Greece: H.A. Mooney and C.E. Conrad (techn. coord.). In Proceedings of the Symposium on the Environmental Consequences of Fire and Fuel Management in Mediterranean Ecosystems, Palo Alto, CA, USA, 1-5 August 1977; pp. 476-482.

54. Arianoutsou, M. Post-fire successional recovery of a phryganic (east Mediterranean) ecosystem. Acta Oecologica Oecologia Plant. 1984, 5, 387-394.

55. Thanos, C.; Marcou, S.; Christodoulakis, D.; Yannitsaros, A. Early post-fire regeneration in Pinus brutia forest ecosystem of Samos island (Greece). Acta Oecologica Oecologia Plant. 1989, 10, 79-94.

56. Hanes, T.L. Succession after fire in the chaparral of southern California. Ecol. Monogr. 1971, 41, 27-52. [CrossRef]

57. Kruger, F.J. Plant community diversity and dynamics in relation to fire. In Mediterranean Type Ecosystems; Kruger, F.J., Mitchell, D.T., Jarvis, J.U., Eds.; Springer: Berlin/Heidelberg, Germany, 1983; pp. 446-472.

58. Papanastasis, V.; Vrachnakis, M.; Iovi, K.; Platis, P.; Karalazos, A.; Hatziminaoglou, I. Dynamics of herbage production in a grazed of mountain grassland in Greece. Multifunction grasslands: Quality forage, animal products and landcapes. In Proceedings of the 19th General Meeting of the European Grassland Federation, La Rochelle, France, 27-30 May 2002; Volume 7, pp. 348-349.

59. Solomou, A.D.; Karetsos, G.; Skoufogianni, E.; Martinos, K.; Sfougaris, A.; Tsagari, K. Assessment of Greek forests protection and management. In Sustainable Development in Mountain Regions; Springer: Berlin/Heidelberg, Germany, 2016; pp. 141-166.

60. Noy-Meir, I. Effects of grazing on Mediterranean grasslands: The community level. In Proceeding of the International Workshop of European Grassland Federation, Ecological Basis of Livestock Grazing in Mediterranean Ecosystems, Thessaloniki, Greece, 23-25 October 1997; pp. 27-39.

61. Thirwood, J.V. Man and the Mediterranean Forest; Academic Press: Cambridge, MA, USA, 1981.

62. Tsoumis, G. The Depletion of Forests in the Mediterranean Region a Historical Review from the Ancient Times to the Present; Scientific Annals of the Department of Forestry and Natural Environment: Thessaloniki, Greece, 1985; p. 281300.

63. Vokou, D.; Diamantopoulos, J.; Mardiris, T.A.; Margaris, N.S. Desertification in northern Greece the case of Kella. In Desertification in Europe; Fantechi, R., Margaris, N.S., Eds.; D. Reidel Publishing Co.: Dordrecht, The Netherlands, 1986; p. 155160.

64. Pantis, J.; Margaris, N.S. Can system dominated by asphodels be considered as semideserts? Int. J. Biometeorol. 1988, $32,8791$. [CrossRef]

65. Papanastasis, V.; Kyriakakis, S.; Ispikoudis, J. Forestry and grazing practices in Crete. In Stability and Change in the Cretan Landscape; Grove, A.T., Moody, J., Rackham, O., Eds.; Petromaroula 1; Corpus Christi College: Cambridge, UK, 1990; p. 446.

66. Anderson, V.J.; Briske, D.D. Herbivore-induced species replacement in grasslands: Is it driven by herbivory tolerance or avoidance? Ecol. Appl. 1995, 5, 1014-1024. [CrossRef]

67. Caldwell, M.M.; Richards, J.H.; Manwaring, J.H.; Eissenstat, D.M. Rapid shifts in phosphate acquisition show direct competition between neighboring plants. Nature 1987, 327, 615-616. [CrossRef]

68. Gomez Sal, A.; De Miguel, J.M.; Casado, M.A.; Pineda, F.D. Successional changes in the morphology and ecological responses of a grazed pasture ecosystem in Central Spain. Vegetatio 1986, 67, 33-44. 
69. Fernandez Ales, R.; Laffarga, J.M.; Ortega, F. Strategies in Mediterranean grassland annuals in relation to stress and disturbance. J. Veg. Sci. 1993, 4, 313-322. [CrossRef]

70. Dale, V.H.; Beyeler, S.C. Challenges in the development and use of ecological indicators. Ecol. Indic. 2001, 1, 155-170. [CrossRef]

71. Dale, V.H.; Beyeler, S.C.; Jackson, B. Understory vegetation indicators of anthropogenic disturbance in longleaf pine forest at Fort Benning, Georgia, USA. Ecol. Indic. 2002, 1, 155-170. [CrossRef]

72. Connell, J.H. Diversity in tropical rain forests and coral reefs. Science 1978, 199, 1302-1310. [CrossRef]

73. White, P.S. Pattern, process, and natural disturbance in vegetation. Bot. Rev. 1979, 45, 229-299. [CrossRef]

74. Huston, M.A. Biological Diversity: The Coexistence of Species on Changing; Cambridge University Press: Cambridge, UK, 1994.

75. Ferris-Kaan, R.; Peace, A.J.; Humphrey, J.W. Assessing structural diversity in managed forest. In Assessment of Biodiversity for Improved Forest Planning; Bachmann, P., Ed.; European Forest Institute Proceedings 18; Kluwer Academic Publishers: Dordrecht, The Netherlands, 1998; pp. 331-342.

76. Kneeshaw, D.D.; Leduc, A.; Drapeau, P.; Gauthier, S.; Pare, D.; Carignan, R.; Doucet, R.; Bouthillier, L.; Messier, C. Development of integrated ecological standards of sustainable forest management at an operational scale. For. Chron. 2000, 76, 481-493. [CrossRef]

77. Zumeta, D.C.; Ellefson, P.V. Conserving the biological diversity of forests: Program and organizational experiences of state governments in the United States. Environ. Manag. 2000, 26, 393-402. [CrossRef]

78. Larsson, S.; Danell, K. Science and the management of boreal forest biodiversity. Scand. J. For. Res. 2001, 3, 5-9. [CrossRef]

79. Beatty, S.W. Influence of microtopography and canopy species on spatial patterns of forest understory plants. Ecology 1984, 65, 1406-1419. [CrossRef]

80. Collins, B.S.; Dunne, K.P.; Pickett, S.T.A. Responses of forest herbs to canopy gaps. In The Ecology of Natural Disturbance and Patch Dynamics; Pickett, S.T.A., White, P.S., Eds.; Academic Press: Orlando, FL, USA, 1985; pp. 217-234.

81. Siccama, T.G.; Bormann, F.H.; Likens, G.E. The Hubbard Brook Ecosystem Study: Productivity, nutrients, and phytosociology of the herbaceous layer. Ecol. Monogr. 1970, 40, 389-402. [CrossRef]

82. Hutchinson, T.F.; Boerner, R.E.J.; Iverson, L.R.; Sutherland, S.; Kenedy-Sutherland, E. Landscape patterns of understory composition and richness across a moisture and nitrogen mineralization gradient in Ohio (U.S.A.) Quercus forests. Plant. Ecol. 1999, 144, 177-189. [CrossRef]

83. Pregitzer, K.S.; Barnes, B.V. The use of ground flora to indicate edaphic factors in upland ecosystems of the McCormick Experimental Forest, Upper Michigan. Can. J. For. Res. 1982, 12, 661-672. [CrossRef]

84. Meilleur, A.; Bouchard, A.; Bergeron, Y. The use of understory species as indicators of landform ecosystem type in heavily disturbed forest: An evaluation in the Haut-SaintLaurent, Quebec. Vegetatio 1992, 102, 13-32. [CrossRef]

85. Laface, V.L.A.; Musarella, C.M.; Cano Ortiz, A.; Quinto Canas, R.; Cannavò, S.; Spampinato, G. Three New Alien Taxa for Europe and a Chorological Update on the Alien Vascular Flora of Calabria (Southern Italy). Plants 2020, 9, 1181. [CrossRef] [PubMed]

86. Levizou, E.; Kyparissis, A. Ecophysiology of Mediterranean Plants; University of Ioannina, Department of Biological Applications and Technology: Ioannina, Greece, 2005; pp. 69-70.

87. Rackham, O.; Moody, J. The Making of the Cretan Landscape; Manchester University Press: Manchester, UK, 1996.

88. Klironomos, J. The actions of fungi in ecosystems. BioScience 2007, 57, 981-982. [CrossRef]

89. Rossman, A.; Tulloss, R.; O’Dell, T.; Thorn, G. Protocols for an All Taxa Biodiversity Inventory of Fungi in a Costa Rican Conservation Area; Parkway Publishers: Blowing Rock, NC, USA, 1998.

90. Dighton, J. Fungi in Ecosystem Processes; Dighton, J., Ed.; CRC Press: Boca Raton, FL, USA, 2003.

91. Heilmann-clausen, J.; Barron, E.S.; Boddy, L.; Dahlberg, A.; Griffith, G.W.; Nord, J.; Ovaskainen, O.; Perini, C.; Senn-irlet, B.; Halme, P. A fungal perspective on conservation biology. Conserv. Biol. 2014, 29, 61-68. [CrossRef] [PubMed]

92. Hoff, J.A.; Klopfenstein, N.B.; Tonn, J.R.; Mcdonald, G.I.; Zambino, P.J.; Rogers, J.D.; Peever, T.L.; Carris, L.M. Roles of Woody Root-Associated Fungi in Forest Ecosystem Processes: Recent Advances in Fungal Identification; General Technical Report; RMRS-RP-47; USDA Forest Service: Washington, DC, USA, 2004.

93. Dahlberg, A.; Genney, D.R.; Heilmann-Clausen, J. Developing a comprehensive strategy for fungal conservation in Europe: Current status and future needs. Fungal Ecol. 2010, 3, 50-64. [CrossRef]

94. Laganà, A.; Salerni, E.; Barluzzi, C.; De Dominics, V.; Perini, C. Fungi (macromycetes) in various types of Mediterranean forest ecosystems (Tuscany, Italy). Pol. Bot. J. 2002, 47, 143-165.

95. Cockle, K.L.; Martin, K.; Robledo, G. Linking fungi, trees, and hole-using birds in a Neotropical tree-cavity network: Pathways of cavity production and implications for conservation. For. Ecol. Manag. 2012, 264, 210-219. [CrossRef]

96. Zervakis, G.I.; Venturella, G. Adverse effects of human activities on the diversity of macrofungi in forest ecosystems. Bocconea 2007, 21, 77-84.

97. Richard, F.; Moreau, P.-A.; Selosse, M.-A.; Gardes, M. Diversity and fruiting patterns of ectomycorrhizal and saprobic fungi in an old growth Mediterranean forest dominated by Quercus ilex. Can. J. Bot. 2004, 82, 1711-1729. [CrossRef]

98. Zotti, M.; Pautasso, M. Macrofungi in Mediterranean Quercus ilex woodlands: Relations to vegetation structure, ecological gradients and higher-taxon approach. Czech. Mycol. 2013, 65, 193-218. [CrossRef]

99. Rodríguez, M.H.; Oria-De-Rueda, J.A.; Martín-Pinto, P. Post-fire fungal succession in a Mediterranean ecosystem dominated by Cistus ladanifer L. Forest Ecol. Manag. 2013, 289, 48-57. [CrossRef]

100. Richard, F.; Millot, S.; Gardes, M.; Selosse, M.-A. Diversity and specificity of ectomycorrhizal fungi retrieved from an old-growth Mediterranean forest dominated by Quercus ilex. New Phytol. 2005, 166, 1011-1023. [CrossRef] 
101. Lancellotti, E.; Schiaffino, A.; Franceschini, A.; Marras, F. Study of the ectomycorrhizal community in a cork oak stand of Sardinia. Micol. Ital. 2007, 36, 89-98.

102. Lonsdale, D.; Pautasso, M.; Holdenrieder, O. Wood-decaying fungi in the forest: Conservation needs and management options. Eur. J. For. Res. 2008, 127, 1-22. [CrossRef]

103. De Dominicis, V.; Barluzzi, C. Coenological research on macrofungi in evergreen oak woods in the hills near Siena (Italy). Vegetatio 1983, 54, 177-187. [CrossRef]

104. Barluzzi, C.; De Dominicis, V.; Perini, C. Primi risultati di indagini micologiche sulle leccete delle colline del litorale grossetano. Micol. Ital. 1983, 12, 29-35.

105. Perini, C.; Barluzzi, V.; De Dominicis, V. Mycocoenological research on evergreen Oak woods in the hills of the Maremma coastline (NW of Grosseto, Italy). Phytocoenologia 1989, 17, 289-306. [CrossRef]

106. Signorello, P. Indagini micocenologiche sulle cenosi a Quercus ilex L. dell'Etna. Micol. Ital. 1996, 25, 74-80.

107. Laganà, A.; Loppi, S.; De Dominicis, V. Relationship between environmental factors and the proportions of fungal trophic groups in forest ecosystems of the central Mediterranean area. For. Ecol. Manag. 1999, 124, 145-151. [CrossRef]

108. Salerni, E.; Laganà, A.; De Dominicis, V. Mycocenological studies in deciduous Oak woods of central-southern Tuscany (Italy). Cryptogam. Mycol. 2001, 22, 35-55. [CrossRef]

109. Santi, E.; Maccheroni, S.; Rocchini, D.; Bonini, I.; Brunialti, G.; Favilli, L.; Perini, C.; Pezzo, F.; Piazzino, S.; Rota, E.; et al. Simple to sample: Vascular plants as surrogate group in a nature reserve. J. Nat. Conserv. 2010, 18, 2-11. [CrossRef]

110. Zotti, M.; Vizzini, A.; Traverso, M.; Boccardo, F.; Pavarino, M.; Mariotti, M.G. The macrofungi checklist of Liguria (Italy): The current status of surveys. Mycotaxon 2008, 105, 167-170.

111. Ortega, A.; Lorite, J. Macrofungi diversity in cork-oak and holm-oak forests in Andalusia (southern Spain); an efficient parameter for establishing priorities for its evaluation and conservation. Cent. Eur. J. Biol. 2007, 2, 276-296. [CrossRef]

112. Halme, P.; Heilmann-Clausen, J.; Rama, T.; Kosonen, T.; Kunttu, P. Monitoring fungal biodiversity-Towards an integrated approach. Fungal Ecol. 2012, 5, 750-758. [CrossRef]

113. Rosa García, R.; Fraser, M.D.; Celaya, R.; Ferreira, L.M.M.; García, U.; Osoro, K. Grazing land management and biodiversity in the Atlantic European heathlands: A review. Agroforest. Syst. 2013, 87, 19-43. [CrossRef]

114. Nauta, M.M.; Jalink, L.M. Grassland in the coastal dunes: The effect of nature management on the mycota. In Fungal Conservation: Issues and Solutions; Moore, D., Nauta, M.M., Evans, S.E., Rotheroe, M., Eds.; British Mycological Society, Cambridge University Press: Cambridge, UK, 2001; pp. 136-143.

115. Raatikainen, K.M.; Heikkinen, R.K.; Pykala, J. Impacts of local and regional factors on vegetation of boreal semi-natural grasslands. Plant Ecol. 2007, 189, 155-173. [CrossRef]

116. Pykala, J. Maintaining Plant Species Richness by Cattle Grazing: Mesic Semi-Natural Grasslands as Focal Habitats; Publications in Botany from the University of Helsinki: Helsinki, Finland, 2007; pp. 36-37.

117. Jakobsson, S. Perinteiset kulttuuribiotoopit. In Suomen Helttasienten ja Tattien Ekologia, Levinneisyys ja Uhanalaisuus; Salo, P., Niemelä, T., Nummela-Salo, U., Ohenoja, E., Eds.; Suomen Ympäristökeskus: Helsinki, Finland, 2005.

118. Olff, H.; Ritchie, M.E. Effects of herbivores on grassland plant diversity. Trends Ecol. Evol. 1998, 13, 261-265. [CrossRef]

119. Mwendera, E.J.; Saleem, M.A.M.; Woldu, Z. Vegetation response to cattle grazing in the Ethiopian highlands. Agric. Ecosyst. Environ. 1997, 64, 43-51. [CrossRef]

120. Pykala, J. Effects of restoration with cattle grazing on plant species composition and richness of semi-natural grasslands. Biodivers. Conserv. 2003, 12, 2211-2226. [CrossRef]

121. Lindborg, R.; Eriksson, O. Historical landscape connectivity affects present plant species diversity. Ecology 2004, 85, 1840-1845. [CrossRef]

122. Poyry, J.; Luoto, M.; Paukkunen, J.; Pykala, J.; Raatikainen, K.; Kuussaari, M. Different responses of plants and herbivore insects to a gradient of vegetation height: An indicator of the vertebrate grazing intensity and successional age. Oikos 2006, 115, 401-412. [CrossRef]

123. Chiarucci, A.; D’Auria, F.; De Dominicis, V.; Laganá, A.; Perini, C.; Salerni, E. Using vascular plants as a surrogate taxon to maximize fungal species richness in reserve design. Conserv. Biol. 2005, 19, 1644-1652. [CrossRef]

124. Brown, N.; Bhagwat, S.; Watkinson, S. Macrofungal diversity in fragmented and disturbed forests of the Western Ghats of India. J. Appl. Ecol. 2006, 43, 11-17. [CrossRef]

125. McMullan-Fisher, S.J.M.; Kirkpatrick, J.B.; May, T.W.; Pharo, E.J. Surrogates for macrofungi and mosses in reservation planning. Conserv. Biol. 2010, 24, 730-736. [CrossRef] [PubMed]

126. Rudolf, K.; Morschhauser, T.; Pál-Fám, F.; Botta-Dukát, Z. Exploring the relationship between macrofungi diversity, abundance, and vascular plant diversity in semi-natural and managed forests in north-east Hungary. Ecol. Res. 2013, 28, 543-552. [CrossRef]

127. Schmit, J.P.; Mueller, G.M.; Leacock, P.R.; Mata, J.L.; Wu, Q.; Huang, Y. Assessment of tree species richness as a surrogate for macrofungal species richness. Biol. Conserv. 2005, 121, 99-110. [CrossRef]

128. Arnolds, E. Decline of ectomycorrhizal fungi in Europe. Agric. Ecosyst. Environ. 1991, 35, 209-244. [CrossRef]

129. Gabel, A.C.; Gabel, M.L. Comparison of diversity of macrofungi and vascular plants at seven sites in the Black Hills of South Dakota. Am. Midl. Nat. 2007, 157, 258-296. [CrossRef]

130. Ruppert, K.M.; Kline, R.J.; Rahman, M.S. Past, Present, and Future Perspectives of Environmental DNA (EDNA) Metabarcoding: A Systematic Review in Methods, Monitoring, and Applications of Global EDNA. Glob. Ecol. Conserv. 2019, 17, e00547. [CrossRef] 
131. Bohmann, K.; Evans, A.; Gilbert, M.T.P.; Carvalho, G.R.; Creer, S.; Knapp, M.; Douglas, W.Y.; De Bruyn, M. Environmental DNA for Wildlife Biology and Biodiversity Monitoring. Trends Ecol. Evol. 2014, 29, 358-367. [CrossRef] [PubMed]

132. Deiner, K.; Bik, H.M.; Mächler, E.; Seymour, M.; Lacoursière-Roussel, A.; Altermatt, F.; Creer, S.; Bista, I.; Lodge, D.M.; De Vere, N. Environmental DNA Metabarcoding: Transforming How We Survey Animal and Plant Communities. Mol. Ecol. 2017, 26, 5872-5895. [CrossRef]

133. Van der Heyde, M.; Bunce, M.; Wardell-Johnson, G.; Fernandes, K.; White, N.E.; Nevill, P. Testing Multiple Substrates for Terrestrial Biodiversity Monitoring Using Environmental DNA Metabarcoding. Mol. Ecol. Resour. 2020, 20, 732-745. [CrossRef]

134. Ekschmitt, K.; Bakonyi, G.; Bongers, M.; Bongers, T.; Boström, S.; Dogan, H.; Harrison, A.; Nagy, P.; O’Donnell, A.G.; Papatheodorou, E.M. Nematode Community Structure as Indicator of Soil Functioning in European Grassland Soils. Eur. J. Soil Biol. 2001, 37, 263-268. [CrossRef]

135. Griffiths, B.S.; Young, I.M.; Caul, S. Nematode and Protozoan Population Dynamics on Decomposing Barley Leaves Incubated at Different Soil Matric Potentials. Pedobiologia 1995, 39, 454-461.

136. Gupta, V.V.; Yeates, G.W. Soil microfauna as bioindicators of soil health. In Biological Indicators of Soil Health; Pankhurst, C., Doube, B.M., Gupta, V.V.S.R., Eds.; CAB International: New York, NY, USA, 1997; pp. 201-233.

137. Elliot, E.T. Rationale for Developing Bioindicators of Soil Health. Biological indicators of soil health. Biol. Indic. Soil Health 1997, 49-78. Available online: https://agris.fao.org/agris-search/search.do;jsessionid=29564E0FFAD720E56AE51D5AE8 5C62E1?request_locale=zh_CN\&recordID=US1997059136\&query=\&sourceQuery=\&sortField=\&sortOrder=\&agrovocString= \&advQuery=\&centerString=\&enableField (accessed on 8 August 2021).

138. Henkin, Z.; Landau, S.Y.; Ungar, E.D.; Perevolotsky, A.; Yehuda, Y.; Sternberg, M. Effect of Timing and Intensity of Grazing on the Herbage Quality of a Mediterranean Rangeland. J. Anim. Feed Sci. 2007, 16, 318-322. [CrossRef]

139. Wang, K.H.; Mcsorley, R.; Bohlen, P.; Gathumbi, S.M. Cattle Grazing Increases Microbial Biomass and Alters Soil Nematode Communities in Subtropical Pastures. Soil Biol. Biochem. 2006, 38, 1956-1965. [CrossRef]

140. Li, Q.; Mayzlish, E.; Shamir, I.; Pen-Mouratov, S.; Sternberg, M.; Steinberger, Y. Impact of Grazing on Soil Biota in a Mediterranean Grassland. Land Degrad. Dev. 2005, 16, 581-592. [CrossRef]

141. Bardgett, R.D.; Leemans, D.K.; Cook, R.; Hobbs, P.J. Seasonality of the Soil Biota of Grazed and Ungrazed Hill Grasslands. Soil Biol. Biochem. 1997, 29, 1285-1294. [CrossRef]

142. Hu, J.; Wu, J.; Ma, M.; Nielsen, U.N.; Wang, J.; Du, G. Nematode Communities Response to Long-Term Grazing Disturbance on Tibetan Plateau. Eur. J. Soil Biol. 2015, 69, 24-32. [CrossRef]

143. Milchunas, D.G.; Sala, O.E.; Lauenroth, W.K. A Generalized Model of the Effects of Grazing by Large Herbivores on Grassland Community Structure. Am. Nat. 1988, 132, 87-106. [CrossRef]

144. Talamucci, P.; Chaulet, C. Contraintes et evolution des ressources fourrageres dans le basin mediterranees. In Proceedings of the XVI International Grassland Congress, Nice, France, 4-11 October 1989; pp. 1731-1740.

145. Le Houerou, H.N. Grazing lands of the Mediterranean basin. In Natural Grassland; Coupland, R.T., Ed.; Ecosystems of the World; Elsevier: Amsterdam, The Netherlands, 1993; Volume 8, pp. 171-196.

146. Papanastasis, V.P.; Mansat, P. Grasslands and related forage resources in Mediterranean areas. In Grasslands and Land Use Systems; Parente, G., Frame, J., Orsi, S., Eds.; Grassland Science in Europe, ERSA: Gorizia, Italy, 1996; Volume 1, pp. 47-57.

147. Bartolomé, J.; Miró, J.; Panadès, X.; Broncano, M.J.; Plaixats, J.; Rigau, T.; Milán, M.J.; Baraza, E. Preference by Donkeys and Goats among Five Mediterranean Forest Species: Implications for Reducing Fire Hazard. Animals 2020, 10, 1302. [CrossRef]

148. Papanastasis, V.P.; Yiakoulaki, M.D.; Decandia, M.; Dini-Papanastasi, O. Integrating Woody Species into Livestock Feeding in the Mediterranean Areas of Europe. Anim. Feed Sci. Technol. 2008, 140, 1-17. [CrossRef]

149. Wilson, A.D. A review of browse in the nutrution of grazing animals. J. Range Manag. 1969, 22, 23-28. [CrossRef]

150. Holechek, J.L. Comparative contribution of grasses, forbs and shrubs to the nutrition of range ungulates. Rangelands 1984, 6 , 261-263.

151. Ramirez, R.G.; Loyo, A.; Mora, R.; Sanchez, E.M.; Chaire, A. Forage intake and nutrition of range goats in a shrubland in northeastern Mexico. J. Anim. Sci. 1991, 69, 879-885. [CrossRef]

152. Nastis, A.S. Nutritive value of fodder shrubs. In Fodder Trees and Shrubs in the Mediterranean Production Systems: Objectives and Expected Results of the EC Research Contract; Papanastasis, V.P., Ed.; Agriculture, Agrimed Research Programme, Commission of the European Communities Report EUR 14459 EN; Commission of the European Communities: Luxembourg, 1993 ; pp. 75-81.

153. Papachristou, T.G. Intake, digestibility and nutrient utilization of oriental hornbeam and manna ash browse by goats and sheep Small Rumin. Res. 1997, 23, 91-98. [CrossRef]

154. Papachristou, T.G. Foraging behaviour of goats and sheep on Mediterranean kermes oak shrublands. Small Rumin. Res. 1997, 24, 85-93. [CrossRef]

155. Papachristou, T.G.; Platis, P.D.; Papanastasis, V.P.; Tsiouvaras, C.N. Use of deciduous woody species as a diet supplement for goats grazing Mediterranean shrublands during the dry season. Anim. Feed Sci. Technol. 1999, 80, 267-279. [CrossRef]

156. Papachristou, T.G.; Nastis, A.S. Diets of goats grazing oak shrublands of varying cover in northern Greece. J. Range Manag. 1993, 6, 220-226. [CrossRef]

157. Dumont, B.; Meuret, M.; Prudhon, M. Direct observation of biting for studying grazing behavior of goats and llamas on garrigue rangelands. Small Rumin. Res. 1995, 16, 27-35. [CrossRef] 
158. Espejo-Diaz, M. Evaluation and improvement of efficacy of animal production systems using natural resources by grazing ruminants in Mediterranean areas. In Optimal Exploitation of Marginal Mediterranean Areas by Extensive Ruminant Production Systems, Proceedings of the International Symposium 18-20 June 1994; Zervas, N.P., Hatziminaoglou, J., Eds.; EAAP Publication: Thessaloniki, Greece, 1996; pp. 105-112.

159. Meuret, M. Food harvesting by small ruminants foraging on rangeland and woodland undergrowth (in French with English abstract). INRA Prod. Anim. 1997, 10, 391-401. [CrossRef]

160. Dini, O. Genetic potential of Robinia pseudoacacia L. In Fodder Trees and Shrubs in the Mediterranean Production Systems: Objectives and Expected Results of the EC Research Contract; Papanastasis, V.P., Ed.; Agriculture, Agrimed Research Programme, Commission of the European Communities EUR 11459 EN; Commission of the European Communities: Luxembourg, 1993; pp. 153-159.

161. Platis, P.D.; Papanastasis, V.P. Productivity of deciduous fodder trees and shrubs in relation to the year of cutting. In Management of Mediterranean Shrublands and Related Forage Resources; REUR Technical Series 28; FAO: Rome, Italy, 1993; pp. $134-136$.

162. Papachristou, T.G.; Papanastasis, V.P. Forage value of Mediterranean deciduous woody fodder species and its implication to management of silvo-pastoral systems for goats. Agrofor. Syst. 1994, 27, 269-282. [CrossRef]

163. Ainalis, A.B.; Tsiouvaras, C.N.; Noitsakis, B.; Papanastasis, V.P. Growth dynamics of some woody fodder plants in relation to spacing and grazing. In Ecological Basis of Livestock Grazing in Mediterranean Ecosystems; Papanastasis, V.P., Ed.; International Workshop, EAAP Publication: Thessaloniki, Greece, 1998; pp. 80-85.

164. Getabalew, M.; Alemneh, T. Factors Affecting the Productivity of Rangelands. J. Plant Sci. Agric. Res. $2019,3,19$.

165. Papanastasis, V.P. Review of papers on woody forage plants. Herba 1993, 6, 28-33.

166. Kebaili, A.; Papanastasis, V.P. Comparison of seasonally available biomass in several woody species of mountainous Mediterranean rangelands. In Animal Production and Natural Resources Utilisation in the Mediterranean Mountain Areas; Georgoudis, A., Rosati, A., Mosconi, C., Eds.; EAAP Scientific Series No. 115; Wageningen Academic Publishers: Wageningen, The Netherlands, 2005; pp. 124-128.

167. Papachristou, T.G.; Dziba, L.E.; Provenza, F.D. Foraging ecology of goats and sheep on wooded rangelands. Small Rumin. Res. 2005, 59, 141-156. [CrossRef]

168. Provenza, F.D. Acquired aversions as the basis for varied diets of ruminants foraging on rangelands. J. Anim. Sci. 1996, 74, 2010-2020. [CrossRef]

169. Sales-Baptista, E.; Ferraz-de-Oliveira, M.I. Grazing in Silvopastoral Systems: Multiple Solutions for Diversified Benefits. Agrofor. Syst. 2021, 95, 1-6. [CrossRef]

170. Biró, M.; Molnár, Z.; Öllerer, K.; Lengyel, A.; Ulicsni, V.; Szabados, K.; Kiš, A.; Perić, R.; Demeter, L.; Babai, D. Conservation and Herding Co-Benefit from Traditional Extensive Wetland Grazing. Agric. Ecosyst. Environ. 2020, 300, 106983. [CrossRef]

171. Öllerer, K.; Varga, A.; Kirby, K.; Demeter, L.; Biró, M.; Bölöni, J.; Molnár, Z. Beyond the obvious impact of domestic livestock grazing on temperate forest vegetation-A global review. Biol. Conserv. 2019, 237, 209-219. [CrossRef]

172. Martin, B.; Coppa, M.; Verdier-Metz, I.; Montel, M.C.; Joy, M.; Casasús, I.; Blanco, M. The contribution of mountain pastures to the link to terroir in dairy and meat products. In Mountain Pastures and Livestock Farming Facing Uncertainty: Environmental, Technical and Socio-Economic Challenges; Casasús, I., Lombardi, G., Eds.; CIHEAM: Zaragoza, Spain, 2016; pp. $105-115$.

173. Santini, F.; Guri, F.; Gomez, Y.; Paloma, S. Labelling of Agricultural and Food Products of Mountain Farming; Joint Research Center Scientific and Policy Reports; Citeseer: Luxembourg, 2013; Volume 154. Available online: http://ec.europa.eu/agriculture/ external-studies/2013/mountain-farming/fulltext_en.pdf (accessed on 20 July 2021).

174. Thénard, V.; Choisis, J.P.; Pagès, Y. Towards sustainable dairy sheep farms based on self-sufficiency: Patterns and environmental issues. Mountain pastures and livestock farming. Options Mediterr. 2016, 116, 81-85.

175. Joy, M.; Sanz, A.; Ripoll, G.; Panea, B.; Ripoll-Bosch, R.; Blasco, I.; Alvarez-Rodriguez, J. Does forage type (grazing vs. hay) fed to ewes before and after lambing affect suckling lambs performance, meat quality and consumer purchase intention? Small Rumin. Res. 2012, 104, 1-9. [CrossRef]

176. Beck, M.R.; Gregorini, P. Animal Design Through Functional Dietary Diversity for Future Productive Landscapes. Front. Sustain. Food Syst. 2021, 5, 138. [CrossRef]

177. Renna, M.; Ravetto Enri, S.; Probo, M.; Lussiana, C.; Malfatto, V.; Battaglini, L.M.; Lonati, M.; Lombardi, G. Alpine grasslands: Relations among botanical and chemical variables affecting animal product quality. In Proceedings of the 19th Meeting of the FAO CIHEAM, Mountain Pastures Network-Mountain Pastures and Livestock Farming Facing Uncertainty: Environmental, Technical and Socio-Economic Challenges; Casasús, I., Lombardi, G., Eds.; CIHEAM: Zaragoza, Spain, 2016; pp. 14-16.

178. Prache, S.; Theriez, M. Traceability of lamb production systems: Carotenoids in plasma and adipose tissue. Anim. Sci. 1999, 69, 29-36. [CrossRef]

179. Joy, M.; Ripoll, G.; Molino, F.; Dervishi, E.; Alvarez-Rodriguez, J. Influence of the type of forage supplied to ewes in pre- and post-partum periods on the meat fatty acids of suckling lambs. Meat Sci. 2012, 90, 775-782. [CrossRef] [PubMed]

180. Álvarez-Rodríguez, J.; Sanz, A.; Delfa, R.; Revilla, R.; Joy, M. Performance and grazing behavior of Churra Tensina sheep stocked under different management systems during lactation on Spanish mountain pastures. Livest. Sci. 2007, 107, 152-161. [CrossRef]

181. Prache, S.; Cornu, A.; Berdague, J.L.; Priolo, A. Traceability of animal feeding diet in the meat and milk of small ruminants. Small Rumin. Res. 2005, 59, 157-168.

182. Priolo, A.; Micol, D.; Agabriel, J.; Prache, S.; Dransfield, E. Effect of grass or concentrate feeding systems on lamb carcass and meat quality. Meat Sci. 2002, 62, 179-185. [CrossRef] 
183. Valvo, M.A.; Lanza, M.; Bella, M.; Fasone, V.; Scerra, M.; Biondi, L.; Priolo, A. Effect of ewe feeding system (grass v. concentrate) on intramuscular fatty acids of lambs raised exclusively on maternal milk. Anim. Sci. 2005, 81, 431-436. [CrossRef]

184. Atti, N.; Rouissi, H.; Othmane, M.H. Milk production, milk fatty acid composition and conjugated linoleic acid (CLA) content in dairy ewes raised on feddlot or grazing pasture. Livest. Sci. 2006, 104, 121-127. [CrossRef]

185. Dewhurst, R.J.; Shingfield, K.J.; Lee, M.R.F.; Scollan, N.D. Increasing the concentrations of beneficial polyunsaturated fatty acids in milk produced by dairy cows in high-forage systems, Anim. Feed Sci. Technol. 2006, 131, 168-206. [CrossRef]

186. Mariaca, R.G.; Berger, T.F.H.; Gauch, R.; Imhof, M.I.; Jeangros Band Bosset, J.O. Occurrence of volatile mono- and sesquiterpenoids in highland and lowland plant species as possible precursors for flavor compounds in milk and dairy products. J. Agric. Food Chem 1997, 45, 4423-4434. [CrossRef]

187. Buchin, S.; Martin, B.; Dupont, D.; Bornard, A.; Achilleos, C. Influence of the composition of Alpine highland pasture on the chemical, rheological and sensory properties of cheese. J. Dairy Res. 1999, 66, 579-588. [CrossRef] [PubMed]

188. Bendall, J.G. Aroma compounds of fresh milk from New Zealand cows fed different diets. J. Agric. Food Chem. 2001, 49, 4825-4832. [CrossRef]

189. Viallon, C.; Martin, B.; Verdier-Metz, I.; Pradel, P.; Garel, J.P.; Coulon, J.B.; Berdagué, J.L. Transfer of monoterpenes and sesquiterpenes from forages into milk fat. Lait 2000, 80, 12-16.

190. De Noni, I.; Battelli, G. Terpenes and fatty acid profiles of milk fat and Bitto cheese as affected by transhumance of cows on different mountain pastures. Food Chem. 2008, 109, 299-309. [CrossRef]

191. Tornambé, G.; Cornu, A.; Verdier-Metz, I.; Pradel, P.; Kondojoyan, N.; Figueredo, G.; Hulin, S.; Martin, B. Addition of pasture plant essential oil in milk: Influence on chemical and sensory properties of milk and cheese. J. Dairy Sci. 2008, 91, 58-69. [CrossRef] [PubMed]

192. Besle, J.M.; Viala, D.; Martin, B.; Pradel, P.; Meunier, B.; Berdagué, J.L.; Fraisse, D.; Lamaison, J.L.; Coulon, J.B. Ultravioletabsorbing compounds in milk are related to the forage polyphenols. J. Dairy Sci. 2010, 93, 2846-2856. [CrossRef] [PubMed]

193. Martin, B.; Verdier-Metz, I.; Buchin, S.; Hurtaud, C.; Coulon, J.B. How does the nature of forages and pastures diversity influence the sensory quality of dairy livestock products? Anim. Sci. 2005, 81, 205-212. [CrossRef]

194. Coppa, M.; Ferlay, A.; Monsallier, F.; Verdier-Metz, I.; Pradel, P.; Didienne, R.; Farruggia, A.; Montel, M.C.; Martin, B. Milk fatty acid composition and cheese texture and appearance from cows fed hay or different grazing systems on upland pastures. J. Dairy Sci. 2011, 94, 1132-1145. [CrossRef] [PubMed]

195. Martin, B.; Lherm, M.; Béranger, C. Evolutions et perspectives de l'élevage des ruminants dans les montagnes françaises. INRA Prod. Anim. 2014, 27, 5-16. [CrossRef]

196. Coppa, M.; Martin, B.; Pradel, P.; Leotta, B.; Priolo, A.; Vasta, V. Effect of a hay-based diet or different upland grazing systems on milk volatile compounds. J. Agric. Food Chem. 2011, 59, 4947-4954. [CrossRef]

197. Mollard, A.; Pecqueur, B. De l'hypothèse au modèle du panier de biens et de services. Histoire succincte d'une recherché. Économie Rurale 2007, 300, 100-114. [CrossRef]

198. Dervillé, M.; Allaire, G. Quelles adaptations possibles à la suppression des quotas pour les filières laitières de montagne? Une approche en termes de régime de concurrence. INRA Prod. Anim. 2014, 27, 17-30. [CrossRef] 